\title{
KUALITAS LAPORAN KEUANGAN DAN KONSERVATISME AKUNTANSI PASCA IFRS DI INDONESIA
}

\author{
Eni Indriani \\ Fakultas Ekonomi dan Bisnis Universitas Mataram \\ eni.indriani@unram.ac.id \\ Robith Hudaya \\ Fakultas Ekonomi dan Bisnis Universitas Mataram \\ robith.hudaya@unram.ac.id \\ Widia Astuti \\ Fakultas Ekonomi dan Bisnis Universitas Mataram \\ widia7@ymail.com
}

\section{Article History:}

Received: 29 Des 2020

Revised: 26 April 2021

Accepted: 26 April 2021
Abstract: Conservatism emerged as a result of the accrual approach in preparing financial statements. Accounting conservatism encourages caution so that companies in their financial reporting do not rush to recognize profits, but recognize losses as soon as possible. This research was conducted with the aim of knowing the effect of accounting conservatism on the quality of financial statements after the convergence of IFRS (International Financial Reporting Standards) in Indonesia at manufacturing companies that experienced investment growth in 2015-2019. In order to achieve the objectives of this study, the empirical model uses a simple linear regression equation, with a feasibility test of the model through the coefficient of determination $\left(R^{2}\right)$ and statistical $t$-test. The results of statistical data processing for 83 sample firms show that the Accounting Conservatism (AC) variable has a t-count value of 6.737 with a variable significance level of 0.000 , this means that Accounting Conservatism (AC) has a significant effect on the quality of financial statements (DACC). The positive direction of the variable coefficient value shows that the independent variable has a positive effect on the dependent variable. This means that the application of convergent Financial Accounting Standards to IFRS in Indonesia provides good news for stakeholders, because it can improve the quality of financial report and reduce motifavation for earnings management practices than can mislead users of financial statements in making economic decisions

Abstrak: Konservatisme muncul sebagai dampak pendekatan akrual dalam penyusunan laporan 
keuangan. Konservatisme akuntansi mendorong kehati-hatian agar perusahaan dalam pelaporan keuangannya untuk tidak terburu-buru dalam mengakui keuntungan, namun mengakui kerugian sesegera mungkin. Penelitian ini diselenggarakan dengan tujuan untuk mengetahui pengaruh konservatisme akuntansi terhadap kualitas laporan keuangan setelah konvergensi IFRS (International Financial Reporting Standard) di Indonesia pada perusahaan manufaktur yang mengalami pertumbuhan investasi pada tahun 2015-2019. Guna mencapai tujuan penelitian ini, model empiris menggunakan persamaan regeresi linier sederhana, dengan uji kelayakan model melalui koefisien determinasi $\left(R^{2}\right)$ dan uji t-statistik. Hasil olah data statistic untuk 83 perusahaan sampel menunjukkan bahwa variabel Konservatisme Akuntansi (KA) memiliki nilai t-hitung sebesar 6,737 dengan tingkat signifikansi variabel sebesar 0,000, ini berarti bahwa Konservatisme Akuntansi (KA) memiliki pengaruh signifikan terhadap kualitas laporan keuangan (DACC). Arah positif pada nilai koefisien variabel menunjukkan bahwa variabel independen berpengaruh positif terhadap variabel dependen. Hal ini berarti bahwa penerapan Standar Akuntansi Keuangan yang konvergen terhadap IFRS di Indonesia memberi berita baik bagi pemangku kepentingan, karena dapat meningkatkan kualitas laporan keuangan dan menurunkan motivasi atas praktik pengelolaan laba yang dapat menyesatkan pengguna laporan keuangan dalam pengambilan keputusan ekonomisnya.

Keywords : Accounting conservatism, quality of financial reports, accounting standards, economic decisions

Kata Kunci: Konservatisme Akuntansi, Kualitas laporan keuangan, Standar akuntansi, keputusan konomis 


\section{Pendahuluan}

Informasi mengenai kinerja keuangan perusahan tersaji dalam suatu laporan keuangan yang menuntut penyajian dan pengungkapan penuh, untuk itu Ikatan Akuntan Indonesia (IAI) menyusun pedoman sebagai suatu standar yang dibukukan dalam Pernyataan Standar Akuntansi Keuangan (PSAK). Namun demikian, dalam penyajian informasi yang berkualitas terdapat satu keterbatasan yang perlu diperhatikan yaitu konservatisme akuntansi. Konservatisme muncul sebagai dampak pendekatan akrual dalam penyusunan laporan keuangan. Dan dampaknya adalah dapat memunculkan fenomena pengelolaan laba (manajemen laba) yang dapat mempengaruhi kualitas laba dan menyebabkan merosotnya relevansi nilai informasi akuntansi.

Konservatisme diartikan sebagai upaya penurunan nilai untuk mengantisipasi ketidakpastian ekonomi. Menurut Soetedjo (2009 : 35) konservatisme merupakan prinsip kehati-hatian, dimana suatu keuntungan yang belum terealisasikan belum boleh diakui sebagai keuntungan, namun suatu kerugian yang belum terealisasi sudah harus diakui. Dicontohkan investasi dalam surat berharga yang apabila pada tanggal neraca memiliki nilai pasar yang lebih tinggi daripada harga historisnya, apabila pada saat itu tidak dijual maka keuntungan dari selisih harga ini berarti masih potensi dan tidak boleh diakui sebagai keuntungan. Namun, apabila sebaliknya harga pasarnya lebih rendah dari harga historisnya meskipun belum dijual, maka kerugian sudah harus diakui. Menurut Watts (2003), konservatisme akuntansi mendorong kehati-hatian agar perusahaan dalam pelaporan keuangannya untuk tidak terburu-buru dalam mengakui keuntungan, namun mengakui kerugian sesegera mungkin.

Konservatisme dalam interpretasi Savitri (2016:21) adalah prinsip kehati-hatian (prudent), yang memiliki kecenderungan pesimisme dimana true value tidak lagi diungkapkan secara tepat tapi cenderung menetapkan angka yang lebih kecil. Dalam penjelasan kontraktual ini, konservatisme akuntansi disebabkan adanya moral hazard dari pihak yang memiliki asimetri informasi, asimetri pendapatan, wawasan terbatas, dan kewajiban terbatas. Konservatisme bisa mengandung perilaku oportunistik manajemen dalam pelaporan keuangan dari segi kontraktual. Perilaku oportunistik manajemen yang didorong oleh motif kontraktual ini memicu praktik manajemen laba, dan jika informasi yang tersaji dalam laporan keuangan dikelola sedemikian rupa guna memenuhi tujuan manajemen, maka akan mengurangi kualitas informasi akuntansi (laporan keuangan) yang relevan dan reliabel. Pada akhirnya pengguna informasi akuntansi akan dapat disesatkan dan berpotensi menanggung kerugian di masa yang akan datang. 
Menilik dampak konservatisme akuntansi terhadap relevansi nilai informasi akuntansi saat ini menjadi lebih krusial karena agenda konvergensi Standar Akuntansi Keuangan terhadap IFRS (International Financial Reporting Standards) yang mengutamakan dasar prinsipil (Principle Based). Zhang (2011) dalam risetnya menemukan bahwa penerapan IFRS berpengaruh positif terhadap kualitas laba, seiring dengan peningkatan angka konservatisme pasca IFRS diadopsi di New Zealand.

Konservatisme akuntansi dapat dilihat dari dua sisi, conditional conservatism dan unconditional conservatism. Pasca IFRS diwajibkan di Eropa, Piet, Dumontier, dan Janin (2010) menemukan bahwa konservatisme kondisional yang diproksikan dengan asimetri antara bad news dan good news menurun pasca adopsi IFRS, namun konservatisme non kondisional sebaliknya mengalami peningkatan dan ini memberi implikasi negatif bagi kualitas informasi akuntansi.

Pasca perubahan penerapan standar akuntansi keuangan di Indonesia dari PSAK (Pernyataan Standar Akuntansi Keuangan) berbasis US GAAP (United Stated General Accepted Accounting Principle) ke konvergensi terhadap IFRS (International Financial Reporting Standard), dari rule based ke principle based, tentunya banyak adaptasi yang dilakukan oleh manajemen dalam pelaporan keuangannya. Salah satu concern dalam PSAK US GAAP adalah Prinsip Konservatisme Akuntansi yang dapat mempengaruhi kualitas informasi akuntansi, dan muaranya akan mempengaruhi pengambilan keputusan ekonomi, salah satunya adalah keputusan investasi. Terlebih pada pasar modal di Indonesia yang memiliki bentuk semi strong bahkan cenderung lemah (weak). Ini yang menarik untuk diteliti lebih lanjut, mengenai pengaruh perubahan standar akuntansi keuangan yang berterima umum di Indonesia terhadap kualitas laporan keuangan. Indikator peningkatan kualitas informasi keuangan yang disajikan oleh perusahaan adalah adanya peningkatan pada nilai investasinya, karena ini berarti investor mendapat sinyal positif dari informasi yang dijadikan dasar pengambilan keputusannya dalam berinvestasi.

\section{Telaah Literatur}

Asumsi dalam teori keagenan menyebutkan bahwa mekanisme dalam pasar yang tidak sempurna, masing-masing pihak yang memiliki kepentingan akan berusaha untuk memaksimalkan utilitas mereka sendiri, dengan mengorbankan kepentingan pemilik kepentingan yang lain. Konflik antara pemegang kepentingan ini dapat diminimalisasi salah satunya adalah melalui pengungkapan informasi oleh manajemen (agen) dalam 
penyajian laporan keuangan. Di samping untuk mengurangi informasi yang asimetris, juga sebagai bentuk pertanggungjawaban oleh manajemen.

Standar Akuntansi Keuangan (SAK) adalah suatu standar yang ditetapkan oleh Ikatan Akuntan Indonesia (IAI) yang berisi standar pelaporan keuangan di Indonesia. Standar Akuntansi Keuangan (SAK) merupakan hasil perumusan Komite Prinsipil Akuntansi Indonesia pada tahun 1994 menggantikan Prinsip Akuntansi Indonesia tahun 1984. SAK di Indonesia sebelum tahun 2012 merupakan adopsi dari standar akuntansi berterima umum di Amerika Serikat (United Stated General Accepted Accounting Principle / US GAAP). Pada tahun 2012 standar akuntansi di Indonesia mengalami perubahan dengan mengkonvergensi Standar Pelaporan Keuangan Internasional IFRS (International Finacial Reporting Standard). Perbedaan kedua standar ini adalah US GAAP menggunakan rule based, sementara IFRS lebih ke principle based. Standar akuntansi keuangan disusun untuk keseragaman laporan keuangan, sehingga memudahkan penyusunan laporan keuangan, memudahkan auditor serta memudahkan pembaca laporan keuangan untuk menginterpretasikan dan membandingkan laporan keuangan entitas yang berbeda.

Laba merupakan elemen laporan keuangan yang sangat penting karena laba digunakan sebagai ringkasan dari kinerja perusahaan oleh banyak pengguna laporan keuangan. Pandangan bahwa angka akrual akan meningkatkan kemampuan laba untuk mengukur kinerja perusahaan dinyatakan oleh FASB, dalam SFAC No. 1, paragraf 44 yang menyebutkan bahwa informasi mengenai laba perusahaan dan komponen-komponennya yang diukur dengan akuntansi akrual secara umum menyediakan suatu indikasi yang lebih baik atas kinerja perusahaan daripada informasi mengenai penerimaan dan pembayaran kas saat ini. Menurut Fanani (2009), jika nilai kualitas akrualnya rendah, distorsi antara laba yang dihasilkan dari akuntansi akrual makin besar dibandingkan dengan akuntansi arus kasnya akan mengakibatkan laba tersebut kurang berkualitas. Sebaliknya, jika nilai kualitas akrualnya tinggi, distorsi antara laba yang dihasilkan dari akuntansi akrual makin rendah dibandingkan dengan akuntansi arus kasnya akan mengakibatkan laba yang dihasilkan berkualitas tinggi.

Watts (2003) mendefinisikan konservatisme sebagai prinsip kehatihatian dalam pelaporan keuangan dimana perusahaan tidak terburu-buru dalam mengakui dan mengukur aktiva dan laba serta segera mengakui kerugian dan hutang yang mempunyai kemungkinan yang terjadi. Penerapan prinsip ini mengakibatkan pilihan metode akuntansi ditujukan pada metode yang melaporkan laba atau aktiva yang lebih rendah serta melaporkan hutang lebih tinggi. Kecenderungan seperti itu terjadi karena 
konservatisme menganut prinsip memperlambat pengakuan pendapatan serta mempercepat pengakuan biaya. Akibatnya, laba yang dilaporkan cenderung terlalu rendah (understatement). Praktek konservatisme akuntansi sering memperlambat atau menunda pengakuan pendapatan yang mungkin terjadi, tetapi mempercepat pengakuan biaya yang mungkin terjadi. Sementara itu dalam penilaian aset dan hutang, aset dinilai pada nilai paling rendah dan sebaliknya, hutang dinilai pada nilai yang paling tinggi.

\section{Metode Penelitian}

Penelitian ini bertujuan untuk mengetahui pengaruh konservatisme akuntansi yang terkandung dalam laporan keuangan terhadap kualitas laporan keuangan. Menurut tingkat eksplanasinya yang bermaksud menjelaskan kedudukan variabel-variabel yang diteliti serta hubungan antara satu variabel dengan variabel lainnya, penelitian ini tergolong penelitian asosiatif yang dilakukan untuk mengetahui hubungan antara dua variabel atau lebih, dimana hasil yang ditemukan akan digunakan untuk membangun suatu teori yang berfungsi untuk menjelaskan, memprediksi, dan mengontrol suatu gejala (Anshori dan Iswati; 2009 : 13). Ditinjau dari data yang digunakan, penelitian ini menggunakan pendekatan kuantitatif yang merupakan penelitian terstruktur dan mengkuantifikasikan data untuk dapat digeneralisasikan. Penelitian ini mengambil lokasi di Indonesia dengan Subyek Perusahaan yang terdaftar pada Industri Manufaktur di Bursa Efek Indonesia (BEI) pada tahun 20152019.

\section{Definisi Operasional Variabel}

Konservatisme akuntansi adalah suatu konsep yang menekankan pada prinsip kehati-hatian, dengan mengakui beban dan kewajiban sesegera mungkin meskipun ada ketidakpastian tentang hasilnya, namun hanya mengakui pendapatan dan aset ketika sudah yakin akan diterima. Pengukuran nilai konservatisme akuntansi dalam penelitian ini menggunakan rumus yang diadaptasi dari Givoly dan Hayn (2000) dengan penekanan pada item-item akrual. 


$$
\mathrm{KA}_{\mathrm{it}}={\underline{\left(N \mathrm{~N}_{i t}+\mathrm{DEP}\right.}}_{\left.\mathrm{Tit}-\mathrm{CFO}_{\mathrm{it}}\right) \times(-1)}^{\mathrm{T} \mathrm{A}_{\mathrm{it}}}
$$

Keterangan :

$\mathrm{KA}_{\text {it }} \quad=$ konservatisme akuntansi perusahan i pada tahun $\mathrm{t}$

$\mathrm{NO}_{\text {it }}=$ laba operasi perusahan i pada tahun $\mathrm{t}$

$\mathrm{DEP}_{\text {it }}=$ depresiasi aset tetap berwujud perusahan $\mathrm{i}$ pada tahun $\mathrm{t}$

$\mathrm{CFO}_{\text {it }}=$ arus kas operasi perusahan i pada tahun $\mathrm{t}$

$\mathrm{TA}_{\text {it }} \quad=$ nilai buku total aset perusahan $\mathrm{i}$ pada tahun $\mathrm{t}$

Perusahaan dikatakan memiliki tingkat konservatisme akuntansi yang tinggi jika $K A_{i t}$ di atas nol (positif) dan sebaliknya perusahaan dikatakan memiliki tingkat konservatisme akuntansi yang rendah jika $K A_{i t}$ di bawah nol (negatif). (Andreas, Ardeni, dan Nugroho ; 2017).

Laporan keuangan yang berkualitas adalah jika informasi yang disajikan berhubungan dengan kinerja keseluruhan perusahaan yang tergambar dalam laba perusahaan dan yang berkaitan dengan kinerja pasar modal yang diwujudkan dalam bentuk imbalan. Ukuran kualitas laporan keuangan diukur melalui discretionary accrual yang dihitung dengan menggunakan Modified Jones Model. Model perhitungannya sebagai berikut:

\section{$\mathrm{Ta}_{i t}=\mathrm{N}_{\text {it }}-\mathrm{CFO}_{\text {it }}$}

Nilai total accrual yang diestimasi dengan persamaan regresi OLS sebagai berikut:

$$
T_{i t} / A_{i t-1}=a\left(1 / A_{i t-1}\right)+a\left(\Delta R e v / A_{i t-1}\right)+a\left(P P E t / A_{i t-1}\right)+e
$$

Dari persamaan regresi diatas, NDA dapat dihitung dengan rumus:

$$
N D A_{i t}=a\left(1 / A_{i t-1}\right)+a\left(\Delta S \text { lesit }_{i t} / A_{i t-1}-\Delta R e c_{i t} / A_{i t-1}\right)+\left(P P E t / A_{i t-1}\right)
$$

Selanjutnya $D A$ dapat dihitung sebagai berikut:

$$
D A_{i t}=\left(T a_{i t} / A_{i t-1}\right)-N D A_{i t}
$$

Keterangan:

$\mathrm{DA}_{\text {it }}=$ Discreationary Accruals perusahaan i pada periode $\mathrm{t}$

NDA $_{\text {it }}=$ Non Discreationary Accruals perusahaan i pada periode $\mathrm{t}$

$\mathrm{TA}_{\text {it }} \quad=$ Total Accruals perusahaan i pada periode $\mathrm{t}$

Nit $=$ Laba bersih perusahaan $\mathrm{i}$ pada periode $\mathrm{t}$

$\mathrm{CFO}_{\text {it }}=$ Aliran kas dari aktivitas perusahaan pada periode $\mathrm{t}$

Ait-1 = Total aktiva perusahaan $\mathrm{i}$ pada periode $\mathrm{t}$

$\triangle$ SALES $_{\text {it }} \quad=$ Selisih sales perusahaan i pada periode $\mathrm{t}$

$\triangle$ Rec $_{\text {it }} \quad=$ Perubahan piutang perusahaan i pada periode $\mathrm{t}$

PPEt $=$ Nilai aktiva tetap (gross) perusahaan i pada periode $\mathrm{t}$

e $\quad=$ error 


\section{Prosedur Analisis Data}

Statistik deskriptif berkenaan dengan deskripsi data misalnya menghitung rata-rata dan varians dari data mentah, mendeksripsikan menggunakan tabel-tabel atau grafik sehingga data mentah lebih mudah dibaca dan lebih bermakna. Statistik deskriptif berkenaan dengan bagaimana data dapat digambarkan (dideskripsikan) atau disimpulkan baik secara numerik (misalnya menghitung rata-rata dan deviasi standar) atau secara grafis (dalam bentuk tabel atau grafik) untuk mendapatkan gambaran sekilas mengenai data tersebut sehingga lebih mudah dibaca dan bermakna. Selanjutnya dilakukan Uji Asumsi Klasik.

Model empiris dalam penelitian ini menggunakan regeresi linier sederhana sebagai berikut.

$\operatorname{DACC}_{\mathrm{it}}=\mathrm{a}_{\mathrm{it}}+\beta_{1} \mathrm{KA}_{\mathrm{it}}+$ ei.

Keterangan:

DACC $_{\text {it }} \quad$ : Kualitas laporan keuangan perusahaan i pada periode $t$

$\mathrm{KA}_{\text {it }} \quad:$ Konservatisme akuntansi perusahaan i pada periode $\mathrm{t}$.

ei : error term.

Ketepatan fungsi regresi sampel dapat diukur dari Goodness of Fit test. Secara statistik dapat diukur dari nilai koefisien determinasi $\left(\mathrm{R}^{2}\right)$, dan nilai uji statistik $\mathrm{t}$.

\section{Deskripsi Data Penelitian}

\section{Hasil Penelitian dan Pembahasan}

Sampel dalam penelitian ini berdasarkan kriteria pemilihan populasi sasaran dan setelah dikalkulasikan dengan formula-formula dari ukuran yang telah diuraikan pada bab tiga untuk masing-masing variable, untuk kemudian di olah dengan bantuan program SPSS (Statistical Product and Service Solutions) versi 25 , diperoleh 83 perusahaan (lampiran 1) yang termasuk dalam sektor industri manufaktur yang terdaftar di Bursa Efek Indonesia (BEI) periode 2015 - 2019.

Tabel Statistik Deskriptif

\begin{tabular}{lr|r|r} 
& & \multicolumn{1}{c}{$\begin{array}{c}\text { Std. } \\
\text { Deviation }\end{array}$} \\
\hline KA & 415 & \multicolumn{1}{c}{ Mean } & -80.9529860 \\
& & 18.408164 & 8 \\
& & 2 & \\
\hline DAcc & 415 & -3.6814315 & 46.7423741 \\
& & & 9 \\
\hline
\end{tabular}

Berdasarkan hasil olah data statistik diketahui nilai rata-rata tingkat konservatisme akuntansi sebesar $-18,4081642$ yang berarti bahwa rata-rata perusahaan manufaktur yang terdaftar di BEI pada tahun 20152019 memiliki tingkat konservatisme akuntansi yang rendah karena angka 
rata-rata berada dibawah nol (negative). Sementara itu nilai rata-rata manajemen laba (Discretionary Accrua) adalah sebesar -3,6814315 yang berarti bahwa terdapat praktik manajemen laba pada perusahaan manufaktur yang terdaftar di BEI pada tahun 2015-2019 dengan pola income decreasing (penurunan laba).

\section{Hasil Uji Asumsi Klasik}

\subsubsection{Hasil Uji Normalitas Data}

Uji normalitas data menggunakan Grafik Normal $P$ - $P$ Plot of Regression Standarized Residual menunjukkan data tidak terdistribusi normal (Lampiran 1.a.), dapat dilihat bahwa titik-titik tidak menyebar dan mengikuti arah garis diagonal, dimana kriteria uji normalitas yang menyebutkan jika data menyebar disekitar garis diagonal dan mengikuti arah garis diagonal atau grafik histogram menunjukkan pola distribusi normal. Untuk mengatasi kendala normalitas data, kemudian dilakukan treaatmen melalui transformasi data variable independent dan dependen. Setelah ditransform dan dilakukan uji normalitas data dengan grafik histogram (lampiran 1.b.) diperoleh sebaran data normal. Data hasil transformasi ini selanjutnya yang diuji.

Uji autokorelasi dilakukan melalui uji Durbin Watson (DW-test). Berdasarkan Hasil Uji diketahui nilai Durbin-Watson (DW) adalah 1,917, dimana nilai batas atas (DU) pada tabel DW dengan tingkat kepercayaan 0,1 adalah 1,376. Oleh karena nilai DW lebih besar daripada DU, maka dapat disimpulkan tidak terdapat autokorelasi pada model regresi.

Uji heteroskedaktisitas menggunakan uji dengan metode grafik Scatterplot, dengan dasar analisis jika tidak ada pola yang jelas, serta titik-titik menyebar di atas dan di bawah angka 0 pada sumbu $Y$ secara acak. Hasil uji pada lampiran 2 dengan menggunakan metode grafik Scatterplot, menunjukkan data tersebar dan tidak memiliki pola yang jelas, dimana titik-titik menyebar di atas dan di bawah angka 0 pada sumbu Y secara acak. Sehingga dapat disimpulkan bahwa tidak terdapat masalah heteroskedastisitas dalam model regresi yang terbentuk pada penelitian ini.

\section{Koefisien Determinasi $\left(\mathbf{R}^{2}\right)$}

Koefisien determinasi merupakan instrumen untuk mengukur kemampuan model dalam menerangkan variasi variabel dependen dengan nilai antara nol (0) dan satu (1). Nilai $\mathrm{R}^{2}$ mendekati 0 berarti kemampuan variabel independen dalam menjelaskan variasi variabel dependen terbatas, sementara nilai yang mendekati 1 berarti variabel independen memiliki kemampuan besar dalam menjelaskan variasi variabel dependen. 
Tabel Hasil Uji Koefisien Determinasi $\left(R^{2}\right)$

\begin{tabular}{|l|c|c|c|c|c|}
\hline Model & $\mathrm{R}$ & $\mathrm{R}$ Square & $\begin{array}{c}\text { Adjusted R } \\
\text { Square }\end{array}$ & $\begin{array}{c}\text { Std. Error of } \\
\text { the Estimate }\end{array}$ & $\begin{array}{c}\text { Durbin- } \\
\text { Watson }\end{array}$ \\
\hline 1 & $.181 \mathrm{a}$ & .033 & .031 & .83585 & 1.917 \\
\hline
\end{tabular}

Nilai Koefisien Determinasi $\left(\mathrm{R}^{2}\right)$ direpresentasikan oleh nilai $R$ square, dimana pada tabel di atas diketahui bahwa nilai $\mathrm{R}^{2}$ adalah sebesar 0,033 yang bermakna bahwa sebesar 3,33\% variabel dependen dipengaruhi oleh variabel independen, dan sisanya sebesar $96,67 \%$ dijelaskan oleh variabel lain diluar variabel yang diteliti. Nilai $R^{2}$ relatif kecil berarti bahwa variabel independen (konservatisme akuntansi) memberi pengaruh yang relative kecil terhadap variabel dependen (kualitas laporan keuangan).

Berikut hasil uji statistik yang telah dilakukan untuk pembentukan model regresi berdasarkan model yang sudah dirancang.

Tabel Hasil Uji Statistik

\begin{tabular}{|cc|r|r|r|r|r|}
\hline & & \multicolumn{2}{|c|}{$\begin{array}{c}\text { Unstandardized } \\
\text { Coefficients }\end{array}$} & $\begin{array}{c}\text { Standardize } \\
\mathrm{d} \\
\text { Coefficients }\end{array}$ & & \multirow{2}{*}{} \\
\cline { 2 - 5 } & Model & \multicolumn{1}{|c|}{ B } & Std. Error & Beta & \multicolumn{1}{c|}{$\mathrm{t}$} & Sig. \\
\hline 1 & (Constant) & 21.040 & .242 & & 87.011 &, 000 \\
& KA & .0691 & .019 & .181 & 3.734 &, 000 \\
\hline
\end{tabular}

Berdasarkan data pada tabel 3 di atas, maka model regresi yang terbentuk atas variabel yang diteliti adalah :

DACC $_{\text {it }}=21,040+0,0691 \mathrm{KA}_{\text {it }}+$ ei.

Berdasarkan tabel di atas menunjukkan bahwa variabel Konservatisme Akuntansi (KA) memiliki nilai t-hitung sebesar 3,734 dengan tingkat signifikansi variabel sebesar 0,000 . Nilai signifikansi variabel independen lebih kecil dari tingkat signifikansi kriteria uji 0,05, sehingga dapat disimpulkan bahwa Konservatisme Akuntansi (KA) memiliki pengaruh signifikan terhadap kualitas laporan keuangan (DACC). Arah positif pada nilai koefisien variabel menunjukkan bahwa variabel independen berpengaruh positif terhadap variabel dependen.

\section{Simpulan}

Hasil uji empiris yang dilakukan terhadap 415 data amatan disimpulkan bahwa Konservatisme berpengaruh terhadap kualitas laporan keuangan setelah konvergensi IFRS di Indonesia pada perusahaan yang mengalami pertumbuhan investasi. Temuan riset ini sejalan dengan hasil riset yang telah dilakukan Zhang (2011) dalam risetnya menemukan bahwa penerapan IFRS berpengaruh positif terhadap kualitas laba, seiring 
dengan peningkatan angka konservatisme pasca IFRS diadopsi di New Zealand. Demikian juga hasil riset Piet, Dumontier, dan Janin (2010) yang menemukan bahwa konservatisme kondisional yang diproksikan dengan asimetri antara bad news dan good news menurun pasca adopsi IFRS, namun konservatisme non kondisional sebaliknya mengalami peningkatan dan ini memberi implikasi negatif bagi kualitas informasi akuntansi.

Hal ini berarti bahwa penerapan Standar Akuntansi Keuangan yang konvergen terhadap IFRS di Indonesia memberi berita baik bagi pemangku kepentingan (stake holders), karena dapat meningkatkan kualitas laporan keuangan dan menurunkan motivasi atas praktik pengelolaan laba yang dapat menyesatkan pengguna laporan keuangan dalam pengambilan keputusan ekonomisnya. Menurut Pham (2009), dampak konservatisme akuntansi terhadap relevansi nilai informasi akuntansi pasca Standar Akuntansi Keuangan terhadap IFRS (International Financial Reporting Standards) diwajibkan memberikan ruang bagi akuntan untuk menggunakan berbagai pertimbangan dalam menyiapkan laporan keuangan dan pengauditannya, dan ini memunculkan asumsi bahwa IFRS menurunkan konservatisme dalam laporan keuangan, karena konservatisme membantu mencegah manajer dari manipulasi pendapatan dan earning per share (EPS).

Mempertimbangkan urgensi riset terkait Standar Akuntansi, maka penting untuk dilakukan penelitian berkelanjutan untuk menyempurnakan temuan yang sudah ada. Pada penelitian ini diketahui bahwa kontribusi variabel independent relative kecil terhadap model yang dibentuk, maka disarankan bagi penelitian pada topik yang sama dimasa yang akan datang untuk menambahkan variabel independent lain yang relevan dan variabel kontrol untuk mencegah adanya hasil perhitungan yang bias. Peneliti selanjutnya juga dapat melakukan penelitian pada sektor industri dengan cakupan yang lebih luas, dan memperhatikan periode dan peristiwa yang melatarbelakangi di sekitar tahun pengamatan. 


\section{DAFTAR PUSTAKA}

Anshori, Muslich dan Sri Iswati. 2009. Buku Ajar Metodologi Penelitian Kuantitatif. Surabaya : Pusat Penerbitan dan Percetakan UNAIR (AUP).

Fanani, Zaenal. 2009. Kualitas Informasi Pelaporan Keuangan : Faktorfaktor Penentu dan Konsekuensi Ekonomik. Disertasi S-3 Program Doktor Ilmu Akuntansi Pascasarjana Fakultas Ekonomi Universitas Brawijaya, Malang.

Ghozali, Imam. 2009. Ekonometrika, Teori, Konsep dan Aplikasi dengan SPSS 17. Semarang : Badan Penerbit Universitas Diponegoro.

Ikatan Akuntan Indonesia. 2012. Standar Akuntansi Keuangan. Jakarta : Salemba Empat.

Pham, Hang Minh. 2009. Accounting Conservatism in IFRS and US GAAP. Inquiry : The University of Arkansas Undergraduate Research Journal, Vol. 10, Article 16.

Piot, Charles, Pascal Dumontier dan Remi Janin. 2010. IFRS Consequences on Accounting Conservatism within Europe. French Agence Nationale Pour la Recherche (ANR).

Savitri, Enni. 2016. Konservatisme Akuntansi, Cara Pengukuran, Tinjauan Empiris, dan Faktor-faktor yang Mempengaruhinya. Yogyakarta : Pustaka Sahla.

Soetedjo, Soegeng. 2009. Pembahasan Pokok-pokok Pikiran Teori Akuntansi Vernon Kam. Airlangga University Press. Surabaya.

Watts, Ross L. 2003. Conservatism in Accounting Part I : Explanations and Implications. SSRN, May 2003.

Watts, R., and J.L. Zimmerman. 1990. Positive Accounting Theory. The Accounting Review. Vol 65, No. 1.

Zhang, Jian. 2011. The effect of IFRS Adoption on Accounting Conservatism - New Zealand Perspective. Disertasi Master of Business Auckland University of Technology. 


\section{Lampiran 1. Grafik Uji Normalitas Data}

a. Grafik Normal P-Plot sebelum Transform Data Normal P-P Plot of Regression Standardized Residual

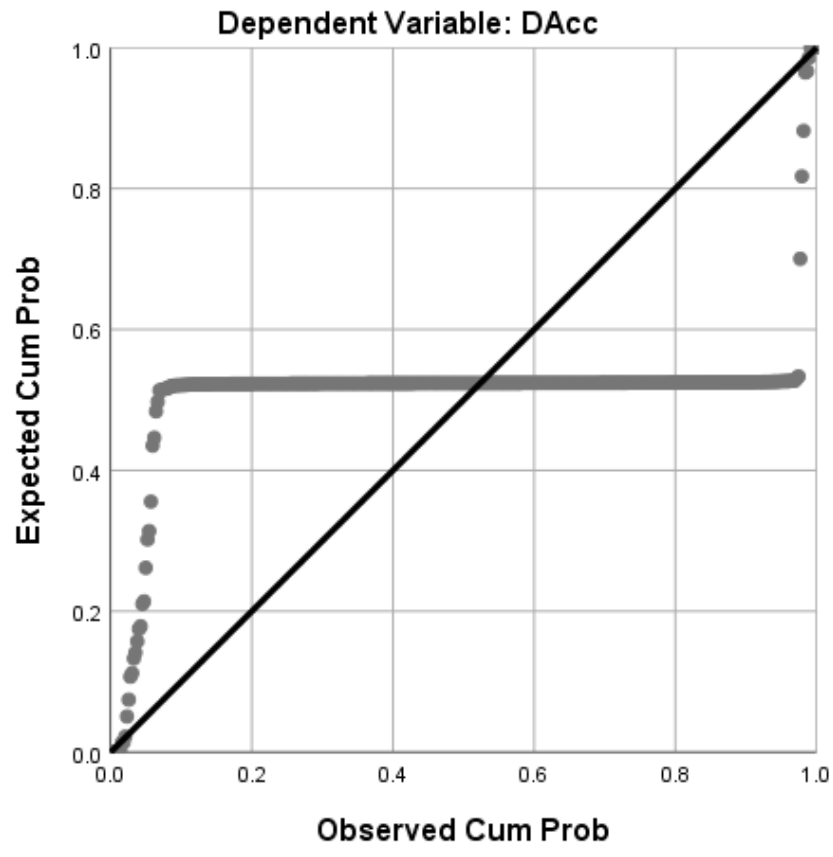

b. Grafik Histogram setelah Transform Data

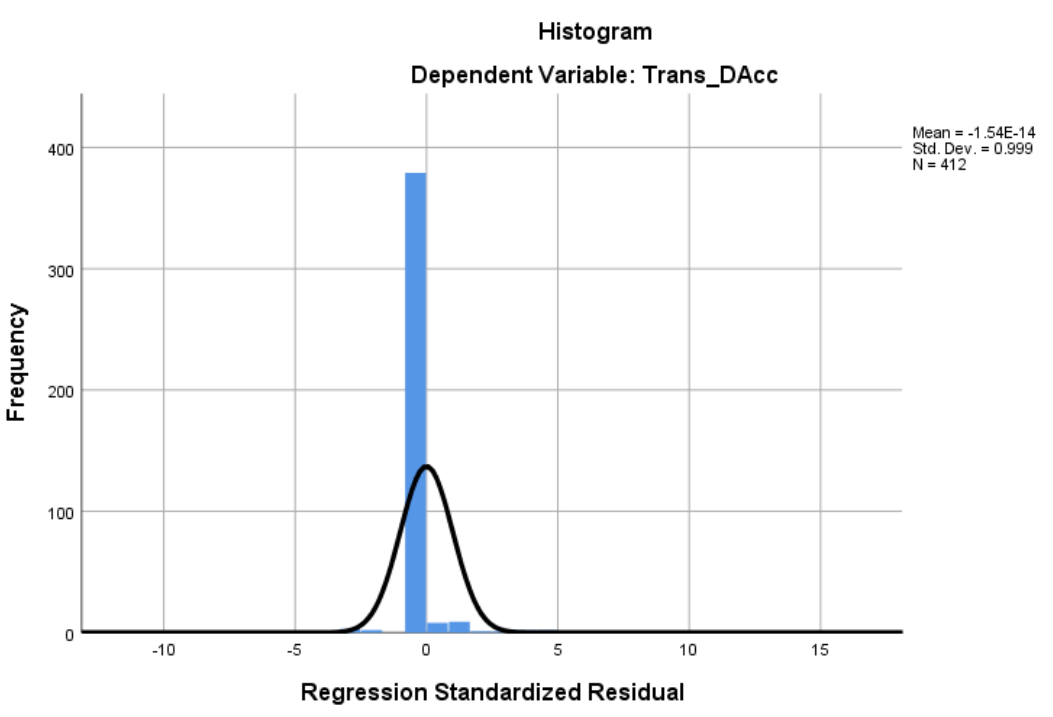




\section{Lampiran 2. Grafik Uji Heteroskedastisitas}

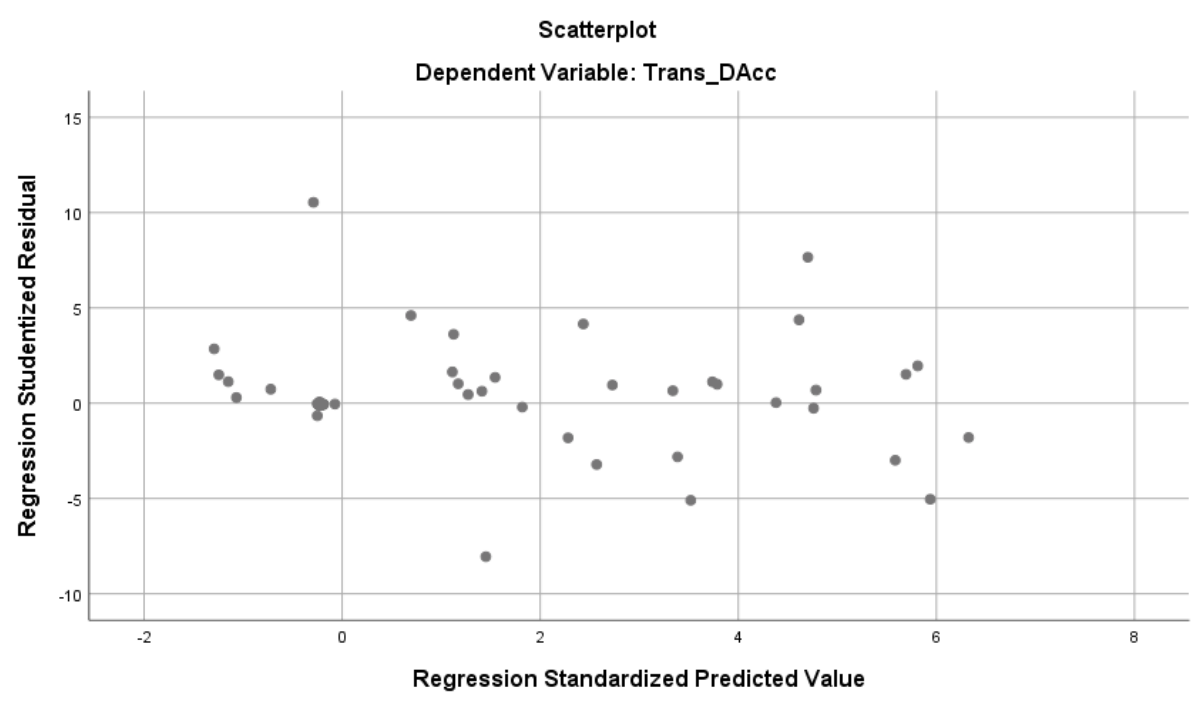

